\title{
0082. Early circulating lipid and cytokine profiles prognosticate in a rat model of faecal peritonitis
}

\author{
W Khaliq ${ }^{*}, M$ Singer \\ From ESICM LIVES 2014 \\ Barcelona, Spain. 27 September - 1 October 2014
}

\section{Introduction}

In stress states, catecholamines induce lipolysis and insulin resistance with hyperglycaemia. Lipid profiles differ between surviving and non-surviving septic patients $[1,2]$ but, hitherto, little attention has been paid to this finding and its significance remains unknown. We used a previously characterized $72 \mathrm{~h}$ fluid-resuscitated rat model of faecal peritonitis where prognostication can be made with high sensitivity and specificity as early as $6 \mathrm{~h}$ from heart rate or stroke volume [3].

\section{Objectives}

To determine the relationship between early changes in plasma cytokine and metabolic profiles, and their prognostic significance.

\section{Methods}

Under general anaesthesia male Wistar rats $(325 \pm 15 \mathrm{~g})$ underwent tunneled insertion of carotid arterial and jugular venous lines, followed by i.p. injection of $4 \mu \mathrm{l} / \mathrm{g}$ faecal slurry. They were then woken and attached to a

swivel-tether system allowing free movement in their cage with, from $2 \mathrm{~h}$, fluid resuscitation ( $1: 1 \mathrm{mix}$ of $5 \%$ dextrose:Hartmann's) at $10 \mathrm{ml} / \mathrm{kg} / \mathrm{h}$. An echocardiography-measured HR cut-off of $460 \mathrm{bpm}$ was used to classify animals into predicted survivors or non-survivors. At $6 \mathrm{~h}$, animals were sacrificed for blood and tissue sampling. We here report plasma levels of IL-6, IL-10, and a metabolic profile using blood gas analysis, ELISA and enzymatic colorometric testing.

\section{Results}

At $6 \mathrm{~h}$ the animals manifested only mild clinical features of illness, however significant differences were seen in IL- 6 and all lipid measurements between predicted survivors and non-survivors. Glucose, lactate and IL-10 levels did not differ. Table 1

\section{Conclusions}

In this long-term rat model of faecal peritonitis, predicted non-survivors had a significantly different IL- 6 and lipid profile as early as 6 hours after sepsis. IL- 6 impacts on

Table 1

\begin{tabular}{ccc}
\hline & Predicted survival $(\mathbf{n}=\mathbf{6})$ & Predicted non-survival $(\mathbf{n}=6)$ \\
\hline IL-6 $(\mathbf{n g} / \mathbf{m L})$ & $0.94 \pm 0.23$ & $3.70 \pm 0.83^{*}$ \\
\hline IL-10 $(\mathbf{n g} / \mathbf{m L})$ & $0.33 \pm 0.05$ & $0.30 \pm 0.12$ \\
\hline Glucose $(\mathbf{m m o l} / \mathbf{L})$ & $6.8 \pm 0.7$ & $6.9 \pm 0.6$ \\
\hline Lactate $(\mathbf{m m o l} / \mathbf{L})$ & $1.9 \pm 0.5$ & $1.6 \pm 0.5$ \\
\hline HDL cholesterol $(\mathbf{m m o l} / \mathbf{L})$ & $0.88 \pm 0.04$ & $0.73 \pm 0.07^{*}$ \\
\hline LDL/VLDL cholesterol $(\mathbf{m m o l} / \mathbf{L})$ & $0.50 \pm 0.03$ & $0.39 \pm 0.03^{*}$ \\
\hline Triglyceride $(\mathbf{m m o l} / \mathbf{L})$ & $1.12 \pm 0.04$ & $0.75 \pm 0.08^{*}$ \\
\hline
\end{tabular}

[Data shown as median $\pm S E ;{ }^{*} p<0.05$ ] 
lipid metabolism [4] but the relationship in sepsis has not, to our knowledge, been previously described. The impact of early hypolipidaemia on outcome warrants further investigation.

\section{Grant acknowledgment}

UK Intensive Care Foundation and NIHR

Published: 26 September 2014

\section{References}

1. Barlage $\mathrm{S}$, et al: Changes in HDL-associated apolipoproteins relate to mortality in human sepsis and correlate to monocyte and platelet activation. Intensive Care Med 2009, 35:1877-1885.

2. Cappi SB, et al: Dyslipidemia: a prospective controlled randomized trial of intensive glycemic control in sepsis. Intensive Care Med 2012, 38:634-641.

3. Rudiger $\mathrm{A}$, et al: Early functional and transcriptomic changes in the myocardium predict outcome in a long-term rat model of sepsis. Clin Sci 2013, 124:391-401.

4. Glund S, Krook A: . Acta Physiol (Oxf). 2008, 192(1):37-48.

doi:10.1186/2197-425X-2-S1-P2

Cite this article as: Khaliq and Singer: 0082. Early circulating lipid and cytokine profiles prognosticate in a rat model of faecal peritonitis. Intensive Care Medicine Experimental 2014 2(Suppl 1):P2.

\section{Submit your manuscript to a SpringerOpen ${ }^{\mathcal{O}}$ journal and benefit from:}

- Convenient online submission

- Rigorous peer review

- Immediate publication on acceptance

- Open access: articles freely available online

- High visibility within the field

- Retaining the copyright to your article 